\title{
MENAKAR PERMASALAHAN PENDIDIKAN ISLAM DALAM PRESFEKTIF ISLAM TRANSITIF
}

\section{Rustam Ependi}

Universitas Pembangunan Panca Budi

J1. Jendral Gatot Subroto KM. 4,5 Sei Sikambing 20122, Medan, Sumatera Utara

e-mail: rustamependi6@gmail.com

\begin{abstract}
Abstrak: Masalah pendidikan di era modern tidak hanya sebatas sistem, metode dan strategi, tetapi lebih kepada bagaimana mempersiapkan generasi yang akan datang. Fenomena di era modern menunjukkan bahwa generasi muda tumbuh dengan sikap individualistis dan pragmatis. Sehingga banyak lulusan lembaga pendidikan yang terjebak dalam memahami ajarannya lebih dalam, sehingga keutamaan Islam yang sebenarnya sangat luas menjadi tersendat dan sempit karena hanya untuk diri sendiri. Perspektif Islam Transitif mensyaratkan bahwa output lulusan lembaga pendidikan Islam adalah agent of change atau transitive. Dalam arti gerakan ke luar, yang tidak hanya egois tetapi juga berusaha agar orang lain mendapatkan keselamatan, keamanan, ketentraman, kemakmuran bahkan kebahagiaan hidup di dunia dan akhirat.
\end{abstract}

Kata Kunci: Pendidikan Islam, Islam Transitif, Problematika Pendidikan

\begin{abstract}
Educational problems in the modern era are not only limited to systems, methods and strategies, but rather how to prepare future generations. The phenomenon in the modern era shows that the younger generation grows with an individualistic and pragmatic attitude. So that many graduates of educational institutions are trapped in understanding their teachings more deeply, so that the virtue of Islam, which is actually very broad, becomes stagnant and narrow because it is only for oneself. The Transitive Islamic perspective requires that the output of the graduates of Islamic education institutions be agents of change or be transitive. In the sense of an outward movement, which is not only selfish but also tries to make other people get safety, security, peace, prosperity and even the happiness of life in this world and the hereafter.
\end{abstract}

Keywords: Islamic Education, Transitive Islam, Educational Problems

\section{PENDAHULUAN}

Berbicara permasalahan yang muncul dalam dunia pendidikan, bagaikan mengurai benang kusut yang sulit dicari mana ujung dan mana pangkalnya. Di mana sulit untuk mengembalikan atau memecahkan masalah tentang pendidikan tersebut. Reformasi di Indonesia seakan menjadi cahaya impian yang memberikan banyak perubahan kehidupan bagi bangsa ini, khusunya pada sektor pendidikan. Akan tetapi, apa yang terjadi kemudian, justru pendidikan di bumi Indonesia semakin menjadi problem baru, yakni lahirnya ambiguisitas dalam wilyah pendidikan yang terus berjalan di Indonesia. Kondisi ironis pendidikan tersebut adalah mengenai goal setting yang ingin dicapai sistem pendidikan. (Hujair A. H. Sanaky, 2008) 
Dalam menghadapi masa depan negara maju dan berkembang telah mengidentifikasikan problema kependidikan masing-masing problema yang mereka temukan pada dasarnya pada kerangka sistem (sistem yang membelenggu kreativitas siswa atau guru) dan metode, apa dan bagaimana pendidikan Islam yang mereka selenggarakan itu mampu berperan secara efektif dan efisien dalam mempersiapkan generasi muda di masa depan. Kualitas sumber daya manusia harus mampu memberdayakan sumber daya alam dan lingkungan yang ada. Tentunya kreativitas serta berfikir kritis merupakan langkah awal untuk membenahi sistem dan metode dalam pembinaan, agar tunas-tunas bangsa memiliki kualitas hidup, dan kehidupan lebih tinggi mutunya dalam segala bidang, tidak saja dalam bidang ilmu pengetahuan dan teknologi, akan tetapi dalam bidang mental dan moralitas salah satu yang tidak boleh dinafikan. (M. Arifin, 1994)

Diakui bahwa berbagai sarana dan fasilitas modern, komunikasi, transportasi, dan industri misalnya, telah terbukti amat bermanfaat bagi kehidupan. Ditemukannya teknologi pesawat telah membuat manusia dapat pergi ke seluruh penjuru dunia dalam waktu yang singkat. Kemajuan di bidang televisi telah memungkinkan manusia untuk melihat berbagai peristiwa penting di tempat yang jauh tanpa harus keluar rumah. Penemuan telepon genggam (seluler) telah memungkinkan kita untuk menghubungi siapa saja dan di mana saja. Kemajuan di bidang komputer telah menciptakan jaringan internet yang memungkinkan manusia untuk mengakses segala informasi dengan mudah, cepat dan akurat. (Muhaimin, 2001)

Seharusnya Keluaran dari tamatan lembaga Pendidikan Islam itu diabad ini harus menjadikan perubahan sebagaimana Menurut Ansari Yamamah "Padahal sesungguhnya Islam itu bersifat transitif yang sejatinya menggambarkan adanya sebuah gerak keluar, yaitu juga wajib berupaya untuk membuat orang lain bisa mendapatkan keselamatan, keamanan, kedamaian, kesejahteraan bahkan kebahagiaan hidup di dunia dan di akhirat kelak. Gagasan Islam Transitif ini menjadi sangat penting, karena umat Islam terutama di era global ini justru sangat banyak yang terperangkap dalam memahami ajarannya lebih ke dalam, sehingga keutamaan Islam yang sesungguhnya sangat luas itu jadi stagnan serta sempit karena hanya untuk diri sendiri. (Ansari Yamamah, Analisadaily, 15 Apr 2019)

Kenyataan demikian tentu akan membawa pengaruh terhadap nilai, sikap, dan perilaku kehidupan individu dan masyarakat. Ada beberapa nilai, sikap dan tingkah laku individu dan masyarakat modern yang kongruen (sejalan) dengan ajaran Islam dan mendukung keberhasilan pembangunan bangsa. (Dwi Priyanto, 2014) Ada pula nilai dan sikap modernitas yang tidak sejalan dengan ajaran Islam sekaligus tidak mendukung keberhasilan pembangunan. Misalnya, lemahnya keyakinan keagamaan, sikap individualistis, materialistis, hedonistis, dan sebagainya. Nilai-nilai dan sikap yang negatif akan muncul bersamaan dengan 
nilai dan sikap positif lainnya, yang sudah barang tentu merupakan ancaman bagi terwujudnya cita-cita pembangunan bangsa.

\section{MEMAHAMI PRINSIP DASAR PENDIDIKAN ISLAM}

Secara epistemologis, pendidikan Islam diletakkan pada dasar-dasar ajaran Islam dan seluruh perangkat kebudayaannya. Dasar-dasar pembcntukan dan pengembangan pendidikan Islam yang pertama dan utama tentu saja adalah Alquran dan Sunnah. (Hasan Langgulung, 1980). Pendidikan Islam pada dasarnya hanya satu, yaitu memanusiakan manusia, atau mengangkat harkat dan martabat manusia atau human dignity, yaitu menjadi khalifah di muka bumi dengan tugas dan tanggung jawab memakmurkan kehidupan dan memelihara lingkungan. Tujuan pendidikan yang selama ini diorientasikan memang sangat ideal bahkan, lantaran terlalu ideal, tujuan tersebut tidak pernah terlaksana dengan baik. Orientasi pendidikan, sebagaimana yang dicitacitakan secara nasional, barangkali dalam konteks era sekarang ini menjadi tidak menentu, atau kabur kehilangan orientasi mengingat adalah tuntutan pola kehidupan pragmatis dalam masyarakat Indonesia. Hal ini patut untuk dikritisi bahwa globalisasi bukan semata mendatangkan efek positif, dengan kemudahan-kemudahan yang ada, akan tetapi berbagai tuntutan kehidupan yang disebabkan olehnya menjadikan disorientasi pendidikan. Pendidikan cenderung berpijak pada kebutuhan pragmatis, atau kebutuhan pasar lapangan, kerja, sehingga ruh pendidikan Islam sebagai pondasi budaya, moralitas, dan social movement (gerakan sosial) menjadi hilang. (Musthofa Rembangy, 2010). Ini Kesalahan umat Islam sekaligus kelemahan dalam meminggirkan konsep dan aktivitas "berproses". Mereka mementingkan hasil dari pada proses yang akibatnya mereka terperangkap dalam sikap dan prilaku instanisme. (Ansari Yamamah, 2019).

Kesadaran atau pandangan hidup masyarakat terhadap diri mereka sendiri. ini yang belum dilakukan pendidikan pendidikan Islam, yaitu menganalisa atau pandangan hidup umat Islam dan bertindak untuk mengadakan perubahan yang lebih baik, lebih jelasnya merubah sistem atau memperbaiki sistem dalam pendidikan Islam itu sendiri baik manajemennya, administrasi kurikulum, pendidik dengan murid, hubungan dengan masyarakat, hubungan denga pemerintah, hubungan dengan orang tua, hubungan dengan lingkungan, dan yang terakhir hubungan dengan Allah. Semua ini harus mencerminkan humanisasi (nguwongke), terhadap murid, mahasiswa dan sebaliknya. Satu sama lain tidak saling menonjolkan diri (mendominasi) akan tetapi bersama untuk yang terbaik insan kamil. (Mansour Fakih, et. al, 2000)

Pendidikan Islam dapat membawa nilai-nilai dan norma-norma kewahyuan bagi kepentingan hidup manusia diatas bumi, bila di interanisasikan kedalam pribadi melalui proses kependidikan yang konsisten dan terarah pada tujuan. Oleh karena itu pendidikan Islam memerlukan kosep-konsep yang pada gilirannya dapat 
dikembangkan menjadi teori-teori teruji dan praksiasi di lapangan operasional.

Bila pendidikan Islam telah menjadi ilmu yang ilmiah dan alamiah maka ia akan berpungsi sebagai sarana pembudayaan manusia yang bernafas islam yang lebih efektif dan efisien. Namun akhir-akhir ini akibat perubahan sosial diberbagai sektor kehidupan umat manusia, beserta nilainilainya ikut mengalami pergesaran yang belum mapan. Sehingga Islam harus mengubah strategi dan taktik operasional. Strategi dan taktik Islam tersebut harus lebih efektif dan efisien artinya pedagogis, Sosiologis dan kultural. Terjadinya pemilihan-pemilihan antara ilmu umum dan ilmu agama inilah yang membawa umat Islam kepada keterbelakangan dan kemunduran paradapan, lantaran karena ilmu-ilmu umum dianggap sesuatu yang berada di luar Islam dan berada diluar Islam dan berasal dari non Islam, bahkan seringkali ditentangkan antara agama dan ilmu (dalam hal ini sains). Agama dianggap tidak adanya kaitannya dengan ilmu, begitu juga ilmu dianggap tidak memperdulikan agama. Begitulah gambaran praktik kependidikan dan aktivitas keilmuan di tanah air sekarang ini dengan berbagai dampak negatif yang ditimbulkan dan dirasakan masyarakat. (Muhaimin, 2006) Padahal menurut Ansari Yamamah kedua kutub keilmuan sains dan agama ini bisa dikolaborasikan disebut teori Symphony (irama), salah satu alasannya bahwa ilmu pada dasarnya berbicara untuk atas kebenaran dan kemaslahatan universalitas kemanusian, walau sekalipun ilmu-ilmu tersebut bersumber dari teks-teks yang berbeda yang sangat kental dengan berbagai dimensi sosiologis baik dalam konteks antologi, epistemologi dan aksiologi. ( Ansari Yamamah, 2019).

Sebagaimana Azyumardi Azra menjelaskan bahwa pendidikan Islam mempunyai beberapa karakteristik, yaitu: Pertama, penekanan pada pencarian ilmu pengetahuan, penguasaan dan pengembangan atas dasar ibadah kepada Allah. Kedua, pengakuan akan potensi dan kemampuan seseorang untuk berkembang dalam suatu kepribadian, setiap pencari ilmu dipandang sebagai makhluk Tuhan yang perlu dihormati dan disantuni, agar potensi-potensi yang dimilikinya dapat teraktualisasi dengan sebaik-baiknya. Ketiga, pengamalan ilmu pengetahuan atas dasar tanggung jawab kepada Tuhan dan masyarakat manusia. Di sini pengetahuan bukan hanya untuk diketahui dan dikembangkan, melainkan sekaligus dipraktekkan dalam kehidupan nyata. Dengan demikian terdapat konsistensi antara apa-apa yang diketahui dengan pengamalannya dalam kehidupan seharihari. ( Azyumardi Azra. 1999)

Pendidikan memang bukan sekadar transfer pengetahuan, pembinaan mental jasmani dan intelek semata, tetapi bagaimana pengetahuan dan pengalaman yang telah didapatkan dipraktekkan dalam prilaku sehari-hari. Ki Hajar Dewantara dalam hal ini menyatakan bahwa pendidikan adalah usaha yang dilakukan dengan penuh keinsyafan yang ditujukan untuk keselamatan dan kebahagiaan manusia. Pendidikan tidak hanya bersifat pelaku pembangunan tetapi sering 
merupakan perjuangan pula. Pendidikan berarti memelihara hidup tumbuh ke arah kemajuan, tidak boleh melanjutkan keadaan kemarin. Pendidikan adalah usaha kebudayaan, berazas peradaban, yakni memajukan hidup agar mempertinggi derajat kemanusiaan. (Abudin Nata, 2001). Dunia dan kehidupan yang akan dihadapi berbeda dengan dunia yang sekarang, untuk itu apa yang akan diberikan pada anak didik harus memperlihatkan kemungkinan relevansi dan kegunaannya di masa datang.

\section{PENYEBAB BENANG KUSUT PENDIDIKAN ISLAM DI INDONESIA}

Pendidikan Islam di era globalisasi saat ini sedang menghadapi tantangan besar, terutama jika dikaitkan dengan konstribusinya terhadap terbentuknya peradaban dan budaya modern yang relevan dengan perkembangan ilmu pengetahuan dan teknologi (IPTEK). Pada dimensi ini, pendidikan (pendidikan Islam khususnya) mengalami kemunduran fungsi (degradasi fungsional) karena pendidikan Islam lebih berorientasi pada aspek kognitif dan bersifat batiniah dogmatis daripada aspek lahiriah eksploratif, Hal ini terjadi sebagai akibat pendidikan Islam kalah bersaing dalam kebudayaan di tingkat global. (M. Mukti Ali, 1998).

Faktor yang melatar belakangi adanya pembaharuan pendidikan Islam pada abad modern dapat dilihat dari dua faktor, yakni Faktor internal dalam dunia pendidikan dan intelektual Islam dan Faktor eksternal, yaitu terjadi kontak anatara pendidikan dengan lingkungan. (Armai Arief. 2009).
1. Problematika Internal Dalam Pendidikan

a. Relasi Kekuasaan dan Orientasi Pendidikan Islam.

Tujuan pendidikan pada dasarnya hanya satu, yaitu memanusiakan manusia, atau mengangkat harkat dan martabat manusia atau human dignity, yaitu menjadi khalifah di muka bumi dengan tugas dan tanggung jawab memakmurkan kehidupan dan memelihara lingkungan. Tujuan pendidikan yang selama ini diorientasikan memang sangat ideal bahkan, lantaran terlalu ideal, tujuan tersebut tidak pernah terlaksana dengan baik. Orientasi pendidikan, sebagaimana yang dicita-citakan secara nasional, barangkali dalam konteks era sekarang ini menjadi tidak menentu, atau kabur kehilangan orientasi mengingat adalah tuntutan pola kehidupan pragmatis dalam masyarakat Indonesia. Hal ini patut untuk dikritisi bahwa globalisasi bukan semata mendatangkan efek positif, dengan kemudahan-kemudahan yang ada, akan tetapi berbagai tuntutan kehidupan yang disebabkan olehnya menjadikan disorientasi pendidikan. Pendidikan cenderung berpijak pada kebutuhan pragmatis, atau kebutuhan pasar lapangan, kerja, sehingga ruh pendidikan Islam sebagai pondasi budaya, moralitas, dan social movement (gerakan sosial) menjadi hilang. (Dwi Priyanto, 2014). Seharusnya Melalui gagasan Islam Transitif Tujuan pendidikan Islam tidak 
boleh stagnan, diam dan pragmatis tetapi harus total produksi bisa menjalankan tugas-tugas kekhalifahan dalam konteks sosial kemasyakatan serta membuat orang lain mendapatkan kesalamatan, keamanan, kedamaian kesejahteran dan kebahagian ketika memiliki pendidikan.

b. Masalah Kurikulum.

Sistem sentralistik terkait erat dengan birokrasi atas bawah yang sifatnya otoriter yang terkesan pihak "bawah" harus melaksanakan seluruh keinginan pihak “atas". Dalam sistem yang seperti ini inovasi dan pembaruan tidak akan muncul. Dalam bidang kurikulum sistem sentralistik ini juga mempengaruhi output pendidikan. Hal ini dapat dicermati dari fenomena berikut: (1) perubahan dari tekanan pada hafalan dan daya ingat tentang teks-teks dari ajaran-ajaran agama islam, serta disiplin mental spiritual sebagaimana pengaruh dari timur tengah, kepada pemahaman tujuan makna dan motivasi beragama islam untuk mencapai tujuan pembelajaran Pendidikan Islam. (2) perubahan dari cara berpikir tekstual, normatif, dan absolutis kepada cara berpikir historis, empiris, dan kontekstual dalam memahami dan menjelaskan ajaranajaran dan nilai-nilai islam.(3) perubahan dari tekanan dari produk atau hasil pemikiran keagamaan islam dari para pendahulunya kepada proses atau metodologinya sehingga menghasilkan produk tersebut. (4) perubahan dari pola pengembangan kurikulum pendidikan
Islam yang hanya mengandalkan pada para pakar dalam memilih dan menyusun isi kurikulum pendidikan islam ke arah keterlibatan yang luas dari para pakar, guru, peserta didik, masyarakat untuk mengidentifikasikan tujuan Pendidikan Islam dan cara-cara mencapainya. (Dwi Priyanto, 2014)

Padahal Kurikulum Pendidikan Islam haruslah digerakkan bukan sentralistik semata, agar roh "gerak" Islam bergeser dari intrnalistik menjadi komunal eksternalistik yang terlepas dari hirarki sosial sekaligus mampu menkolaborasikan setiap unit sosial untuk memainkan perannya dalam pembangunan kehidupan sosial menuju pendidikan yang kuat kreatif, maju dan bermartabat di tengah-tengah modernisasi. (Ansari Yamamah, 2019). c. Pendekatan/Metode Pembelajaran.

Peran guru atau dosen sangat besar dalam meningkatkan kualitas kompetensi siswa/mahasiswa. Dalam mengajar, ia harus mampu membangkitkan potensi guru, memotivasi, memberikan suntikan dan menggerakkan siswa/mahasiswa melalui pola pembelajaran yang kreatif dan kontekstual (konteks sekarang menggunakan teknologi yang memadai). Pola pembelajaran yang demikian akan menunjang tercapainya sekolah yang unggul dan kualitas lulusan yang siap bersaing dalam arus perkembangan zaman. Siswa atau mahasiswa bukanlah manusia yang tidak memiliki pengalaman. 
Sebaliknya, berjuta-juta pengalaman yang cukup beragam ternyata ia miliki. Oleh karena itu, dikelas pun siswa harus kritis membaca kenyataan kelas, dan siap mengkritisinya. Bertolak dari kondisi ideal tersebut, kita menyadari, hingga sekarang ini siswa masih banyak yang senang diajar dengan metode yang konservatif, seperti ceramah, didikte, karena lebih sederhana dan tidak ada tantangan untuk berpikir. (Dwi Priyanto, 2014).

Saat ini banyak anggapan yang menilai guru kurang serius dalam mengembangkan profesinya. Hal ini dapat dilihat dari guru yang tidak mempunyai persiapan mengajar dan kurang minatnya guru dalam mengembangkan kualitas dirinya. Guru dituntut untuk dapat mengembangkan bahan ajar, namun saat ini banyak guru yang kurang antusias dalam menjalankan profesinya khususnya dalam mengembangkan bahan ajar. Menurunnya produktivitas guru ini sangat disayangkan mengingat banyaknya manfaat yang diperoleh dari pengembangan bahan ajar. Pentingnya pengembangan bahan ajar ini karena bahan ajar harus sesuai dengan tuntutan kurikulum, karakteristik siswa, dan dapat memecahkan masalah dalam pembelajaran. Menurunnya kualitas dan produktivitas guru dalam memenuhi tuntutan pengembangkan bahan ajar mungkin disebabkan karena adanya masalah dan keterbatasan. Hal ini berkaitan dengan situasi yang dialami oleh pribadi guru sehari-hari. Salah satu cara untuk mengatasi masalah atau keterbatasan dalam pengembangkan bahan ajar oleh guru adalah dengan memposisikan individu, dalam hal ini guru untuk menggambarkan situasi pengalaman dimana mereka merasa dapat mengembangkan bahan ajar dan dimana mereka tidak mampu mengembangkannya. Oleh karena itu diperlukan adanya sebuah seni yang dapat mengkaloborasikan berbagai instrumen keilmauan untuk memainkan peran sehingga melahirkan sympony (irama) keilmuan untuk memperbaiki kualitas. (Ansari Yamamah, 2019)

d. Profesionalitas dan Kualitas SDM.

Salah satu masalah besar yang dihadapi dunia pendidikan di Indonesia sejak masa Orde Baru adalah profesionalisme guru dan tenaga pendidik yang masih belum memadai. Secara kuantitatif, jumlah guru dan tenaga kependidikan lainnya agaknya sudah cukup memadai, tetapi dari segi mutu dan profesionalisme masih belum memenuhi harapan. Banyak guru dan tenaga kependidikan. (Dwi Priyanto, 2014). Guru merupakan ujung tombak pendidikan. Sebagai pendidik, guru harusmemiliki kompetensi-kompetensi tertentu agar mampu mendidik anak didiknya dengan baik. Menurut UU No.14 Tahun 2005 pasal 10 ayat 1, kompetensi yang harus dimiliki oleh guru meliputi kompetensi pedagogik, kompetensi kepribadian, kompetensi sosial, dan kompetensi profesional yang diperoleh melalui pendidikan profesi. Tugas guru adalah menyampaikan ilmu. 
Ilmu yang disampaikan oleh guru akan lebih bermanfaat apabila penyampaiannya juga dilakukan melaui karya tulis ilmiah karena tidak hanya dapat dinikmati oleh anak didiknya, namun juga oleh masyarakat luas. Sekarang maslah-masalah yang dihadapi pendidikan dalam tenaga guru adalah keprofesionalan guru, kelayakan mengajar dan kesejahteran guru.

Sebagaimana menurut gagasan Islam transitif salah satu cara untuk menjaga eksitensi keberlangsungan kemajuan diri atau hidup yaitu menjaga dan mengembangkan dan memaksimalkan akal melalui pendidikan dari berbagai akademik sehingga suatu saat menjadi total produksi melahirkan insan kamil. (Ansari Yamamah, 2019)

2. Problematika Eksternal Dalam Pendidikan

Dewasa ini globalisasi sudah mulai menjadi permasalahan aktual pendidikan. Permasalahan globalisasi dalam bidang pendidikan terutama menyangkut output pendidikan. Seperti diketahui, di era globalisasi dewasa ini telah terjadi pergeseran paradigma tentang keunggulan suatu Negara, dari keunggulan komparatif (Comparative advantage) kepada keunggulan kompetitif (competitive advantage). Keunggulan komparatif bertumpu pada kekayaan sumber daya alam, sementara keunggulan kompetitif bertumpu pada pemilikan sumber daya manusia (SDM) yang berkualitas. (Kuntowijoyo, 2001)
Hasil studi yang dilakukan oleh Inkeles dan Smith di enam negara berkembang (Argentina, Bangladesh, Chili, India, Israel dan Nigeria) menunjukkan bahwa, sikap atau tingkah laku individu dalam kehidupan era modern meliputi: (1) keterbukaan terhadap pengalaman baru; (2) kesiapan untuk menerima perubahan-perubahan social; (3) efficacy, yakni kepercayaan atas kemampuan manusia dengan ipteknya untuk menguasai dan mengatur lingkungan alamnya (sebagai lawan fatalism); (4) kebiasaan merencanakan dan bekerja tepat waktu; (5) berorientasi ke masa depan; (6) percaya kepada orang lain tanpa prasangka buruk; (7) kecendrungan melepaskan diri dari ikatan-ikatan keluarga besar (individualism); lemahnya keyakinan keagamaan (sebagai akibat tumbuhnya sekularisme ekstrim); (9) aktif mencari informasi dan fakta melalui media massa; (10) preferensi (lebih senang) hidup di kota untuk mengejar kemajuan, atau mengejar karir. (Muhaimin, 2003)

Dalam perbincangan tentang pendidikan, seringkali dihadapkan pada dua orientasi pendidikan yang saling bertolak belakang, satu sisi lebih menekankan pada aspek humaniora dan yang lain lebih berorientasi pada penguasaan pengetahuan dan hi-tech. Kemajuan manusia yang bertitik tumpu di bidang keilmuan selamanya tidak akan memberikan kepuasan bagi kehidupan manusia, karena itu terdapat suatu kesadaran baru untuk kembali 
pada nilai- nilai agama. Dalam kedudukannya agama sebagian dari sistem nilai, agama hanya akan mengalami proses revitalisasi. Dalam rangka revitalisasi dan transformasi nilai- nilai agama adalah bagaimana merekonstruksi peran agama tersebut. Peran itu dapat dilakukan, manakala dalam agama tersedia formulasiformulasi sistem nilai yang lengkap, yakni totalitas sistem makna yang berlaku bagi seluruh kehidupan, baik individu maupun sosial. (Fadjar, A. Malik, 1999).

3. Pemetaan Masalah Menuju Pendidikan Islam Bermutu.

Mutu pendidikan merupakan hal yang harus diperhatikan dan diupayakan untuk dicapai. Sebab pendidikan akan menjadi sia-sia bila mutu proses dan lulusannya rendah, tidak terbangun jiwa jika out put pendidikannya menambah beban masyarakat, keluarga, dan negaranya. (Ahmad Baharuddin, 2007)

Langkah awal yang diperhatikan untuk melakukan pemetaan permasalahn pendidikan Islam, harus menganalisis dari aspek kekuatan, kelemahan, kesempatan, dan ancaman. Pertama, pendidikan Islam (pesantren, madrasah, sekolah yang bercirikan Islam, dan perguruan tinggi) lebih besar $>80 \%$ dikelola oleh swasta. Dalam pengelolaannya lebih percaya dan hormat pada ulama, percaya bahwa guru mengajarkan sesuatu yang benar, panggilan agama, ibadah, ikhlas, murah, merakyat. Hal ini merupakan kekuatan dalam pengelolaan pendidikan Islam. Kedua, kelemahan, bahwa pendidikan Islam posisinya lemah, tidak profesional hampir disemua sektor dan komponennya, stress, terombangambing antara jati dirinya, apakah ikut model sekolah umum atau antara ikut Diknas dan Depag. Belum ada sistem yang mantap dalam pengembangan model pendidikan agama dan pendidikan keagamaan. Ketiga, kesempatan bahwa dalam UU No.20 Th. 2003 memberi kesempatan atau momentum pengembangan pendidikan agama dan keagamaan. Pendidikan Islam diakui sama dengan pendidikan yang lain. Keempat, ancaman bahwa banyak lembaga pendidikan lain yang lebih tangguh dan berkualitas, Ilmu dan teknologi yang berkembang sangat pesat berlum terkejar oleh pendidikan Islam, pendidikan Islam kehilangan jati dirinya, pendidikan Islam selalu menjadi warga kelas dua, tercabut dari akar budaya komunitas muslimnya. (Mastuhu, 2003).

Maka, tidak ada alasan lain bagi umat Islam (ilmuwan, pelaku pendidikan, cendekiawan dan pemikir Muslim) untuk tidak berpikir tentang semua cabang ilmu, khususnya sains dan teknologi yang dianak-tirikan. Sebab, efek negatif dari globalisasi dan krisis lingkungan hidup dalam millenium baru ini, harus dihadapi oleh agama yang notabene selalu mendidik ke arah perdamaian, keadilan, dan kesejahteraan hidup. Itu pula yang dihadapi oleh pendidikan Islam, 
sekarang dan yang akan datang. Padahal kita semua tahu, bahwa persoalan internal Pendidikan Islam sendiri, baik secara kelembagaan maupun secara keilmuan, masih menghadapi persoalan-persoalan klasik yang belum terpecahkan sampai sekarang, dari persoalan manajemen, ketenagaan, sumber dana, sampai ke masalah infrastruktur dan kurikulum. Beratnya masalah itu mengakibatkan, di samping mutu Pendidikan Islam sangat rendah, juga para pengelola Pendidikan Islam tidak lagi sempat dan atau mampu mengantisipasi adanya tantangan globalisasi yang sudah begitu jelas menghadang di hadapannya. (Abdul Munir Mulkhan, at.al, 2004)

Perlakuan pemerintah dan masyarakat terhadap pendidikan Islam masih tetap sama, diskriminatif. Sikap inilah yang menyebabkan pendidikan Islam sampai detik ini terpinggirkan. Terpinggirnya pendidikan Islam dari persaingan sesungguhnya dikarenakan dua faktor, yaitu faktor internal dan eksternal. Faktor internal, pertama, meliputi manajemen pendidikan Islam yang pada umumnya belum mampu menyelenggarakan pembelajaran dan pengelolaan pendidikan yang efektif dan berkualitas. Hal ini tercermin dari kalah bersaing dengan sekolah-sekolah yang berada di bawah pembinaan Kementrian Pendidikan Nasional (Diknas) yang umumnya dikelola secara modern. Kedua, faktor kompensasi profesional guru yang masih sangat rendah. Para guru yang merupakan unsur terpenting dalam kegiatan belajar mengajar, umumnya lemah dalam penguasaan materi bidang studi, terutama menyangkut bidang studi umum, keterampilan mengajar, manajemen kelas, dan motivasi mengajar. Hal ini terjadi karena sistem pendidikan Islam kurang kondusif bagi pengembangan kompetensi profesional guru. Ketiga, adalah faktor kepemimpinan, artinya tidak sedikit kepala-kepala madrasah yang tidak memiliki visi, dan misi untuk mau ke mana pendidikan akan dibawa dan dikembangkan. Kepala madrasah seharusnya merupakan simbol keunggulan dalam kepemimpinan, moral, intelektual dan profesional dalam lingkungan lembaga pendidikan formal, ternyata sulit ditemukan di lapangan pendidikan Islam. (Hujair A. H. Sanaky, 2008).

Namun masalah pendidikan memang tidak akan pernah selesai dibicarakan. Hal ini setidak-tidaknya didasarkan pada beberapa alasan pertama, merupakan fitrah setiap orang bahwa mereka menginginkan pendidikan yang lebih baik sekalipun mereka kadang-kadang belum tau mana sebenarnya pendidikan yang lebih baik itu, karena merupakan fitrah, sehingga sudah menjadi takdirnya pendidikan itu tidak akan pernah selesai. Kedua, teori pendidikan akan selalu ketinggalan zaman,karena ia dibuat berdasarkan kebutuhan masyarakat yang selalu berubah pada setiap tempat dan waktu. Karena adanya perubahan itu maka 
masyarakat tidak akan pernah puas dengan teori pendidikan yang ada, dan yang ketiga, perubahan pandangan hidup jugaikut berpengaruh terhadap ketidak puasan seseorang akan keadaan pendidikan, sehingga pada suatu saat seseorang akan puas dengan sistem pendidikan yang ada karena sesuai dengan pandangan hidupnya, dan pada saat yang lain seseorang bisa terpengaruh oleh pandangan hidup lainnya yang pada gilirannya berubah pula pendapatnya tentang pendidikan yang semula dianggap memuaskannya tersebut. (Muhaimin, 2006)

Inovasi atau penataan fungsi pendidikan Islam harus dilakukan, terutama pada sistem pendidikan persekolahan harus diupayakan secara terus menerus, berkesinambungan, berkelanjutan, sehingga usahanya dapat menjangkau pada perluasan dan pengembangan sistem pendidikan Islam luar sekolah. Harus dilakukan inovasi kelembagaan dan tenaga kependidikan. Tenaga kependidikan harus ditingkatkan etos kerja dan profesionalismenya. Perbaikan pada aspek materi (kurikulum), pendekatan, dan metodologi yang masih berorientasi pada sistem tradisional, perbaikan pada aspek manajemen pendidikan itu sendiri. Tetapi usaha melakukan inovasi tidak hanya sekedar tanbal sulam, tetapi harus secara mendasar dan menyeluruh, mulai dari fungsi, tujuan, metode, strategi, materi (kurikulum), lembaga pendidikan, dan pengelolaannya. Dengan kata lain, penataan pendidikan
Islam haruslah bersifat komprehensif dan menyeluruh. (Azyumardi Azra, 2002).

\section{SIMPULAN}

Menakar Permasalahan Pendidikan Islam Presfektif Islam Transitif Pertama, Pendidikan Islam diletakkan pada dasardasar ajaran Islam dan seluruh perangkat kebudayaannya. Dasar-dasar pembentukan dan pengembangan pendidikan Islam yang pertama dan utama tentu saja adalah Alquran dan Sunnah Kedua, Pendidikan Islam di era globalisasi saat ini sedang menghadapi tantangan besar, terutama jika dikaitkan dengan konstribusinya terhadap terbentuknya peradaban dan budaya modern yang relevan dengan perkembangan ilmu pengetahuan dan teknologi (IPTEK). Pada dimensi ini, pendidikan (pendidikan Islam khususnya) mengalami kemunduran fungsi (degradasi fungsional) karena pendidikan Islam lebih berorientasi pada aspek kognitif dan bersifat batiniah dogmatis dari pada aspek lahiriah eksploratif seharusnya mempunyai roh "gerak" Ketiga, Mutu pendidikan merupakan hal yang harus diperhatikan dan diupayakan untuk dicapai. Sebab pendidikan akan menjadi sia-sia bila mutu proses dan lulusannya rendah, tidak terbangun jiwa jika out put pendidikannya menambah beban masyarakat, keluarga, dan negaranya maka diperlukan pendidikan kaloborasi disebut Sympony (irama) agar tujuan pendidikan Islam membentuk peradaban tinggi dimasa depan 


\section{DAFTAR PUSTAKA}

Ansari Yamamah, Islam Transitif Filsafat Milenial, (Jakarta: Kencana Prena Grup Media, 2019).

Azyumardi Azra, Pendidikan Islam Tradisi dan Modernisasi Menuju Milenium Baru, (Jakarta: PT. Logos Wacana Ilmu, 1999).

Paradigma Baru Pendidikan Nasional, Rekonstruksi dan Demokratisasi, (Jakarta: Penerbit Buku Kompas, 2002), h. 17.

Abudin Nata, Filsafat Pendidikan Islam, (Jakarta: Logos Wacana Ilmu, 2001).

Armai Arief, Pembaharuan Pendidikan Islam di Minangkabau cet. ke1,(Jakarta: $\quad$ Suara Adi, , 2009).

Abdul Munir Mulkhan dkk., Pendidikan Islam dan Tantangan Globalisasi (Yogyakarta: Presma UIN Yogyakarta, 2004)

Dwi Priyanto, Pemetaan Problematika Integrasi Pendidikan Agama Islam Dengan Sains Dan Teknologi, Insania, Vol. 19, No. 2, Juli Desember 2014.

Hujair A. H. Sanaky, Permasalahan dan Penataan Pendidikan Islam Menuju Pendidikan yang Bermutu, el Tarbawy Jurnal Pendidikan Islam, NO. $\quad$ 1. VOL. I. 2008.

Hasan Langgulun, Beberapa Pemikiran tentang Pendidikan lstam, Bandung: Al-Ma'anf, 1980).

M. Arifin, Ilmu Perbandingan Pendidikan, (Jakarta: PT Rineka Cipta,1994).

Muhaimin, Paradigma Pendidikan Islam, Upaya Mengefektifkan Pendidikan Agama di Sekolah. (Bandung: Rosdakarya, 2001)
------------, Arah Pengembangan Pendidikan Islam Pemberdayaan, Pengembangan Kurikulum Hingga Redefinisi Islamisasi Pengetahuan. (Bandung: Nuansa. 2003).

Pustaka Setia, 2006).

Mansour Fakih, et.al, Raharjo, Toto (ed.), Pendidikan Populer; Panduan Pendidikan untuk Rakyat, (Yogyakarta: Pustaka Pelajar, 2000).

M. Mukti Ali, Membangun Moralitas Bangsa (Yogyakarta: LPPI, UMY, 1998).

Musthofa Rembangy, Pendidikan Transformatif: Pergulatan Kritis Merumuskan Pendidikan di Tengah Pusaran Arus Globalisasi, (Yogyakarta: Teras, 2010).

Kuntowijoyo, Muslim Tanpa Masjid: EsaiEsai Agama, Budaya, dan Politik dalam Bingkai Strukturalisme Transendental, Bandung: Mizan, 2001).

Fadjar, A. Malik, Reorientasi Pendidikan Islam, (Jakarta: Fajar Dunia, 1999).

Ahmad Baharuddin, Pendidikan Alternatif Qaryah Thayyibah, (Yogyakarta: LKiS, 2007).

Mastuhu, Menata Ulang Pemikiran Sistem Pendidikan Nasional dalam Abad 21, (Yogyakarta Safiria insane Press, 2003) 